EASTERN REVIEW 2019, T. 8

\author{
Ivana Jolović \\ (iD) https://orcid.org/0000-0002-6167-2965 \\ University of Novi Sad, Novi Sad, Serbia \\ Faculty of Technical Sciences \\ e-mail: ivanajolovic@uns.ac.rs \\ Alpar Lošonc \\ (iD) https://orcid.org/0000-0002-5046-6170 \\ University of Novi Sad, Novi Sad, Serbia \\ Faculty of Technical Sciences \\ e-mail: alpar@uns.ac.rs
}

\title{
The impact of foreign direct investment and venture capital investment on entrepreneurship in the Republic of Serbia
}

\begin{abstract}
The subject of the research is the examination of features and significance of two modern types of investment intended for financing entrepreneurship: that is, foreign direct investment and venture capital investment. The starting point of the study is the sector of small and medium-sized enterprises and entrepreneurs with all the challenges and opportunities that characterize its financial position in the Republic of Serbia. The aim of this research is to analyse the impact of both direct investment and entrepreneurial capital investment on small businesses, or more precisely, to examine the influence of foreign direct investment and venture capital investment on entrepreneurship. This paper focuses on the impact that these types of financing have on management structure, financial stability, and the performance of the relevant business entities. Consequently, the current status and perspectives of these types of financing are analysed in detail. The conducted research, also, aims to provide an answer to the dilemma which type of investment is currently a more favourable solution for financial problems with which Serbian entrepreneurs are faced. A detailed analysis of the content of national and European statistical reports; available national and foreign literature of domestic and international authors; and descriptive and comparative method were used for the preparation of this paper.
\end{abstract}

Keywords: foreign direct investment, venture capital investment, entrepreneurship, Republic of Serbia. 


\section{Introduction}

Business entities in countries in transition are faced with numerous challenges, especially financial ones. Businesses that are particularly affected are: entrepreneurs that, in the beginning, do their business in industries that are closely related to technologies and innovations; and small and medium-sized enterprises that start stagnating due to insufficient financial funds or development ideas. Considering the nature of their activities, their short presence in the market, and the low amount of share capital, these business entities are rarely accepted by banks as loan applicants. This unfavourable position results in the failure of many business entities on an annual basis, adding to an increase in unemployment and a decrease in the economic growth of the country. A country that is worried about the position of these entities (primarily because these business entities employ most of the working age population) often takes many measures for promoting their business activities by allowing them access to capital, subsidies, or tax incentives. However, the country's effort in financing does not completely solve the problem that these entities are faced with.

Although there is an opinion among business entities that there is not enough capital in the national market for financing all of them, this is not always seen as such within scientific circles. Namely, numerous authors claim the contrary: that the banking sector has enough funds, but they do not want to invest because of the high risk of the entities applying for loans. Recognising the problems that have been present in this market segment for decades, the Republic of Serbia has decided to address this problem and to make available alternative types of funding to the business entities, in addition to the traditional ones provided by banks. Owing to the efforts of the state, the market has been gradually adjusting to the European legislative framework for years in terms of adopting legal and legislative regulations that allow additional foreign capital inflow into the national market.

Foreign direct investments have for many years been the most popular form of capital investment by foreign investors in business entities outside their domestic market. This type of capital, especially in the Republic of Serbia, is mostly provided for standard entrepreneurs, small and medium-sized enterprises while the demand for capital for many high-risk businesses in this sector is rarely satisfied. The potential solution to this problem can be found in the examples of good practice in the European market, which ensures the success of their smallest entities through venture capital investment.

This paper aims at providing insight into the effects that foreign direct investments and venture capital investments have on the Serbian market of small and start-up businesses; as well as at showing the academic community the possibilities that will open up on the Serbian capital market in the near future due to the changes in legislation. The relevance of this research is confirmed by the aforementioned measures that the Government has taken and continues to take in the field of investment policy, 
and which obviously produce results: since the Republic of Serbia is a country that many investors choose to invest in.

Considering the presented problems and aims of the research, the basic hypothesis about the research has been defined in the following way:

- H0: 'Foreign direct investment and venture capital investment have a positive impact on entrepreneurship in the Republic of Serbia'.

Specific hypotheses which are closely related to the basic one and which determine it more precisely are defined in the following manner:

- H1: 'Financing Serbian entrepreneurship with foreign direct investments influences the empowerment of entrepreneurial businesses due to the involvement of new players in the management structure of these entities';

- H2: 'Financing Serbian entrepreneurship with venture capital investments influences the development of ideas and innovations and encourages the technological development of entrepreneurial entities';

- H3: 'Financing Serbian entrepreneurship with foreign direct investment and venture capital investment influences the increase of the financial stability of entrepreneurial entities and their chances of survival in the market'.

During the preparation of this paper, and with the aim of confirming the constructed hypotheses, the following methods were used: analysis of the content of national financial and statistical reports and documents; analysis of available national and foreign literature of the relevant domestic and international authors in the field of foreign direct investments, venture capital investments and entrepreneurship; as well as descriptive and comparative methods.

\section{A literature overview and theoretical considerations on investments}

In the modern global environment, the growth and operation of a national economy greatly depend on the relationship and connections that it establishes with the rest of the world. The nature and intensity of these relationships are, apart from trade, increasingly marked by investment flows that enable internationalisation and integration in the dynamics of the world market (Nestorović, 2015). Therefore, the monitoring and analysis of investments and their flows are particularly important in both developed and less developed countries. One of the most popular investments certainly are foreign capital investments.

\section{Determination of foreign direct investment in theory}

Foreign direct investments represent the category of cross-border investments that are made by a resident in one economy (direct investor) with the aim of taking a permanent interest in or control of a company in another country (OECD, 
2008). To be more precise, foreign direct investments are investments that result from using foreign accumulations for the purpose of investing in national companies that have a high demand for capital (Nestorović, 2015). According to many authors, foreign direct investments represent the most significant part of international capital flows. In the context of globalization and the new economic order, these investments play the role of an important lever for economic growth (Ignjatijević, 2015).

After analysing the performances of foreign direct investments, it can be concluded that these investments have become one of the most important pillars of global economic growth over the last few decades, and the significance that these investments have for developing countries, including the Republic of Serbia, is particularly important. Namely, most developing countries and countries in transition are characterised by a lack of their own (national) capital. These countries are given the opportunity to be subject of successful changes in economic structure and to adjust to the demands of the world market by attracting foreign direct investments as an additional financing source (Milovanović et al., 2018). The basic aims of these countries are related to achieving stability, long-term economic growth, and development based on the increase in investments, improvement in the technological base of a country, and the improvement of product competitiveness in the international market. Therefore, these investments can play an important role in fulfilling the aims of the country, that is, they can contribute to the process of transition directly (through capital inflow) and indirectly (through the transfer of managerial, production and organisational know-how; furthermore, improvement can be achieved through the creation of a new sales channel for national companies, by improving competition and restructuring the processes in the national economy) (Stefanović, 2008).

Foreign direct investments are essentially different from other types of foreign investment. Foreign direct investments are only those investments that a foreign investor invests in the establishment and foundation of a new company; or investments which they use to buy shares (namely, directly acquires an ownership interest) in an already existing company. This purchase enables the investor to become an owner with the right to control and manage the company in a foreign economy (Makroekonomija, 2013). The role of the mentioned investor can be performed by: a company, individual or a group of companies, group of individuals, government bodies, other organisations, or any other combination of the mentioned entities. In the case that two companies both have $10 \%$ or more share of the receiving company, they are both considered to be foreign direct investors in the other company (Kastratović, 2016).

Foreign direct investments can appear in two forms in the market and those are (Makroekonomija, 2013):

- establishment of a company as a form of foreign direct investments - this form of foreign investment implies the establishment of a company and 
the creation of production and other capacities by a foreign investor. Investment in a brand-new economic entity is called a 'greenfield investment'. Investors are very cautious when it comes to selecting the market in which they will invest their capital. In the process of selection, they consider the two most important criteria - the safety of investments and the nature of the overall long-term interest they can achieve in the capital importing countries;

- buying stocks or shares in an already existing company as a form of foreign direct investment - this is a form of foreign investment done by acquiring a majority ownership interest in an already existing company in the following way: purchasing the company through the process of privatisation; or through buying stocks or directly getting ownership interest (acquisition) in a company. These types of investments are known as 'brownfield investments', and they are considerably faster and simpler for investors compared to the types of investments related to establishing a company. This is the reason why the focus of this paper will be on them.

Many discussions have been had about the impact of foreign direct investments on a national economy, trade, and the unemployment rate. Recent research papers have tried to analyse the impact that foreign direct investments have on a national economy, and the empirical results have shown that the consequences can be quite different. Namely, some studies have shown that foreign direct investments can stimulate economic growth while others have indicated that foreign direct investments can neutralise this growth and income in the host country (Šabić et al., 2012). Nevertheless, numerous authors believe that the role and significance of foreign direct investments for the economic growth of a country cannot be overstated and questioned. This attitude they explain by the fact that even the strong, stable economies of the world develop policies that will create a favourable investment climate for them (Šušić, Spasojević, 2016).

In a potential host country, foreign direct investment brings an integrated package of tangible and intangible resources (capital, technology, management, marketing, organisational knowledge, workforce training, etc.) that serve as an alternative to labor migration and as a stimulus for economic development. On the one hand, the investment package is a supplement to the available domestic factors of production and creates conditions for new employment and work, while on the other hand, it stimulates the growth of the host country through the transfer of technology, the training of the labor force, the establishment of relationships with other parts of the economy and the opening of the way for domestic producers to enter the world market (Vidas-Bubanja, 1998).

It is important to emphasise the privileges that investors provide to the companies with this type of investment, which relate to: product placement and expansion in the market of the capital exporting country, import of technology from that country, and the capitalisation of managerial knowledge and experience. 
The last listed item can be characterised as a crucial factor since a large number of entrepreneurs stop working in the first few years of doing business due to the mistakes that insufficiently experienced and skilled managers make (Makroekonomija, 2013). These mistakes are minimised when a foreign direct investor sends to a company their management team which thoroughly analyses the market, competition, and possibilities for the progress of the mentioned company. This type of support enables entrepreneurs, in which the capital is invested, to gain an advantage over the other participants in the market.

Finally, it is important to emphasise that although foreign direct investments operate in an almost identical way in each state, they have different determinations (by countries) in terms of the threshold for foreign ownership interest which gives to the investment the status of foreign direct investment. It is the level of participation in a voting share portfolio of ordinary shares that provides decisive influence in the management of the company's operations. This ownership interest's threshold for controlling the invested funds ranges from $10 \%$ to $50 \%$ (Stefanović, 2008).

\section{Determination of venture capital investment in theory}

Venture capital investments represent the type of financing that enables entrepreneurs or other small businesses to raise capital. Venture capital investors tend to invest in high risk/high income companies, based on the size of a company, property, and stage of development of their products (Investopedia, 2019). The demand for venture capital that can be invested, is justified by the inadequate structure and regulations that prevail in the relevant capital markets. Entrepreneurs who have ideas or develop new technology often have no one to rely on for financial support during the early stage of their business development. State laws limit the interest rate that banks can charge when giving loans, and risks related to start-up and technologically oriented companies usually require higher interest rates than those stipulated by law. This is the reason why banks offer financing for new entrepreneurs only in situations when there are significant funds that can secure the mentioned loans. These situations resulted in the creation of a new type of investment - venture capital investments (Zider, 1998).

Specifically, this type of financing was identified in the USA where, in the 1950s, these investments emerged as a response to the need for the financing of entrepreneurs, small and medium-sized enterprises which were established for the purpose of using the possibilities offered by technological advancement. When developing their new products, these risky entrepreneurs (without established creditworthiness or collateral) expressed the need for additional capital but they were rejected as unacceptable 'service buyers' for traditional commercial and investment banks because of their characteristics. The alternative for them 
was provided by capitalists who devised the new financing system. This system enabled the entrepreneurs to use the required capital in exchange for a share in the ownership interest that would bring profit to the potential investor over a certain period of time.

Essentially, this type of investment is based on believing in an idea, an entrepreneur, or an entrepreneur's vision of running a business, which means that investors believe that the company will succeed in the market in the near future. Investors ready for such risky ventures typically invest in several businesses and expect from at least one of those entrepreneurs to meet their expectations and make a return that is sufficient to compensate for the losses caused by investing in a significant number of other similar but unsuccessful ventures. Venture capital investors (or their executives) are not often involved in the management structure of a company, yet, as members of the board of directors, they have the right to participate in all major decisions about the business of their 'financial protégés'.

As mentioned above, this type of investment is typical for a company with high growth potential and substantial risk (UNCTAD Secretariat, 1997). Venture capital investment is good financial support for entrepreneurs who are in the following development stages (Invest Europe, 2019b):

- 'seed' development stage - funds are provided for businesses that have not yet started mass production/distribution. Financing can provide the conditions for: completing the research, defining or designing the product, ensuring that market tests are conducted, and that prototypes are created. Therefore, these funds do not serve to initiate the mass production/distribution;

- 'start-up' development stage - funds are provided to businesses after the product or service is completely developed so that its mass production/distribution can start and can cover the costs associated with initial marketing investment. The companies in question are those which are in the process of foundation or may have been operating for a short time but have not yet had the chance to sell their products for commercial purposes. The invested capital is mostly intended to cover capital expenditures and initial reversible capital. This stage can involve the investments of the 'second early stage' which involves providing funds to the companies that have already started commercial production, but they need financial coverage for additional capital expenditures and reversible capital before penetrating the market;

- 'later-stage financing' - this is the late stage in which funds are provided to operating companies that may or may not be profitable.

Therefore, it can be concluded that venture capital funds play an important role in all stages of the innovation life cycle, and especially in the period when a company begins to commercialise its idea. It is estimated that more than $80 \%$ of the funds that venture capitalists invest in the company are intended for: building the infrastructure necessary for business growth, investment costs (production, marketing, and sales), 
and balance sheet items (providing fixed and current assets). Therefore, venture capital is not long-term money. The idea of its investment is to finance the items in the balance sheet and the infrastructure of a company until it reaches an adequate size and credibility to be sold to a larger corporation or continue to operate successfully as an independent entity (Zider, 1998).

The characteristics of the venture capital investments are as follows (Metrick, 2007; Milenković, Kalaš, 2018):

- investments are made only in private businesses - these are the companies which stocks are not listed on stock exchanges so they cannot be traded within the same;

- by investing, the investors get minority ownership interest in a company - this share allows the investor to have an influence on the business decisions of a company and with the simple market offer of this share the investor can earn money;

- institutional investors have the right to make their knowledge, technologies, and management teams available to the companies - this is one of the most important characteristics of the investment. Namely, investors are given the opportunity to monitor the day-to-day activities of entrepreneurs and have an influence on their decision-making by suggesting and directing entrepreneurs towards new, technologically supported ways of doing business;

- exit strategy - it is possible to exit the investment by selling, redemption or providing an initial public offering of a share in the company in the case where the investor is forced to act in this way or when they estimate that this will maximise their invested capital;

- capital acquired in this way is invested in the internal growth of a company - investments can be related to the acquisition of the required fixed and current assets for the production process, the development of a product or technology needed for the same.

\section{Foreign direct investment and venture capital investment in the Republic of Serbia}

Foreign capital represents the most important means of the economic recovery and further development of the Serbian economy; and the foreign capital inflow strategy must become the backbone of the economic and development policy of a country that pursues such goals. Foreign direct investment and venture capital investment represent the most important additional source of financing the economic development of the national economy. They are especially important for the interests of the Serbian economy which is characterised by low accumulation capacity and minimal domestic 
savings. However, a much more significant role of these investments is related to their impact on accelerating the transition process, that is, on building the missing institutional and physical infrastructure. They have a positive effect on strengthening the competitiveness of the national economy as well as accelerating the privatisation process (Nestorović, 2015).

\section{Foreign direct investment in the Republic of Serbia}

Later in this paper, it will be discussed about the trends of foreign direct investments recorded in the Republic of Serbia over the past decade; and about their relationship with the most important macroeconomic indicator of the state of the economy - the gross domestic product (GDP). Firstly, however, there will be analysed the relationship between net foreign direct investments and real GDP growth over the period of eleven years (from 2008 until 2018). A growth of net foreign direct investments should contribute to a growth of real GDP or to the decrease in the oscillatory growth rate of the real GDP (Milovanovic et al., 2018), which has occurred in the Republic of Serbia. The data in Table 1 show that there was a steady growth in net foreign direct investments in the Republic of Serbia from 2012 onwards (especially in the final three years of the period). In 2018, the value of these investments was $€ 3,187.9$ million, which represents an increase of approximately $22 \%$ compared to the previously observed period (2008). In the observed period, the value of the GDP of the state was at a relatively similar level with a tendency for a steady increase. In 2018, it amounted to $€ 42,780.0$ million. The encouraging fact is that the value of foreign direct investment held an increasingly significant share in the value of GDP, that is, it had a constant upward trend from 2012 when its minimum was recorded (2.23\%). In 2018, this percentage was 7.45 .

For the purpose of providing a more detailed overview of the situation with foreign direct investments in the Republic of Serbia, the following figure is presented and shows the inflows and outflows of foreign direct investments in the period from 2008 to 2018. Net investments in 2018 amounted to $\$ 3,762$ million, which was precisely the result of the record investments made by investors in the form of foreign direct investment in the last observed year. Such tendencies are expected to have continued in 2019, which is great news for entrepreneurs, small and medium-sized enterprises that are heavily dependent on funding from these sources. In the observed period, the highest inflow of foreign direct investment was recorded in 2011, when it amounted to $\$ 4,932.3$ million, while the record outflow of foreign direct investment was recorded last year (\$363.5 million in 2018). 
Table 1. Trends in foreign direct investments (FDI) and GDP in the period from 2008 to 2018 in the Republic of Serbia

\begin{tabular}{|c|c|c|c|c|c|}
\hline Year & $\begin{array}{c}\text { Net FDI (millions } \\
\text { of euros) }\end{array}$ & $\begin{array}{c}\text { GDP (millions } \\
\text { of euros) }\end{array}$ & $\begin{array}{c}\text { Increase in } \\
\text { net FDI (\%) }\end{array}$ & $\begin{array}{c}\text { Real GDP } \\
\text { growth (\%) }\end{array}$ & $\begin{array}{c}\text { FDI/GDP } \\
\text { (\%) }\end{array}$ \\
\hline $\mathbf{2 0 0 8}$ & $2,485.7$ & $35,712.5$ & 7.0 & 5.7 & 6.96 \\
\hline $\mathbf{2 0 0 9}$ & $2,067.8$ & $32,486.2$ & 6.4 & -2.7 & 6.36 \\
\hline $\mathbf{2 0 1 0}$ & $1,133.4$ & $31,545.8$ & 3.6 & 0.7 & 3.59 \\
\hline $\mathbf{2 0 1 1}$ & $3,319.6$ & $35,431.7$ & 9.4 & 2.0 & 9.37 \\
\hline $\mathbf{2 0 1 2}$ & 752.8 & $33,679.3$ & 2.2 & -0.7 & 2.23 \\
\hline $\mathbf{2 0 1 3}$ & $1,298.1$ & $36,426.7$ & 3.6 & 2.9 & 3.56 \\
\hline $\mathbf{2 0 1 4}$ & $1,236.3$ & $35,467.5$ & 3.5 & -1.6 & 3.49 \\
\hline $\mathbf{2 0 1 5}$ & $1,803.8$ & $35,715.6$ & 5.1 & 1.8 & 5.05 \\
\hline $\mathbf{2 0 1 6}$ & $1,899.2$ & $36,723.1$ & 5.2 & 3.3 & 5.17 \\
\hline $\mathbf{2 0 1 7}$ & $2,418.1$ & $39,183.3$ & 6.2 & 2.0 & 6.17 \\
\hline $\mathbf{2 0 1 8}$ & $3,187.9$ & $42,780.0$ & 7.5 & 4.3 & 7.45 \\
\hline
\end{tabular}

Source: Authors, according to data obtained from the Ministry of Finance of the Republic of Serbia, 2019b.

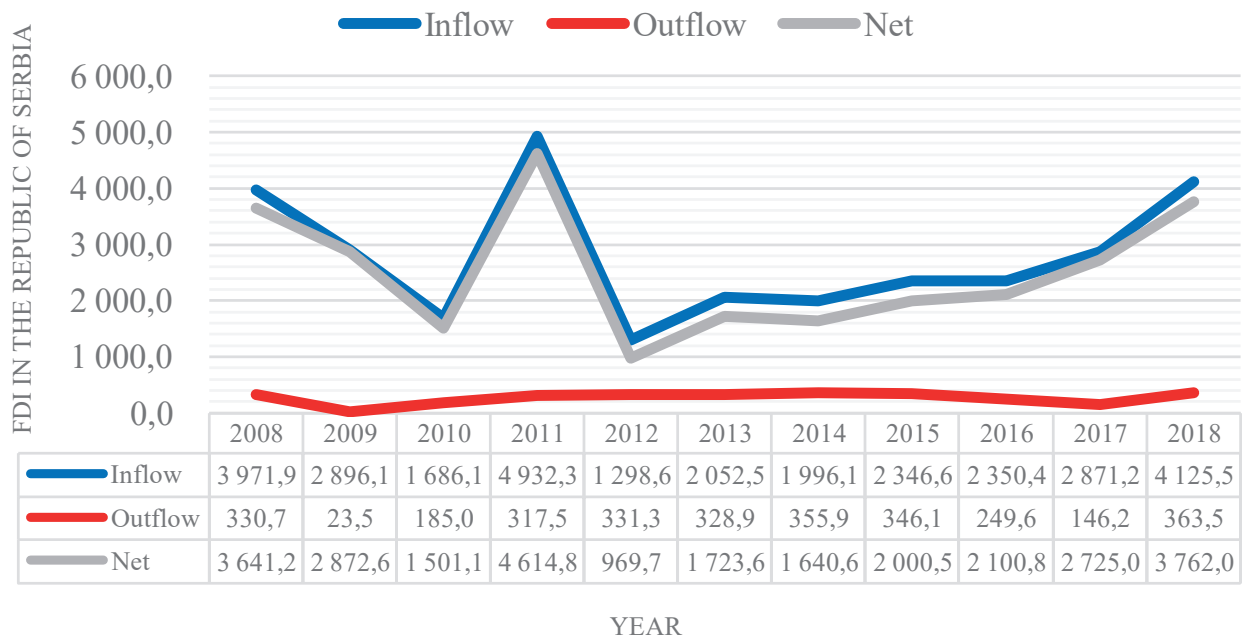

Figure 1. Foreign direct investments in the Republic of Serbia in the period from 2008 to 2018 (in millions of dollars)

Source: Authors, according to data obtained from the UNCTAD, 2019a; 2019b. 


\section{Venture capital investment in the Republic of Serbia}

After presenting the main tendencies regarding foreign direct investments in the Republic of Serbia, the attention will be diverted to the consideration of additional alternative sources of funding in the form of venture capital investments. Although there are no classic venture capital funds in the Republic of Serbia (which are the main holders of this type of financing), it is important to know that Serbian companies have at their disposal venture capital financing mechanisms from the institutions of the European Union, that is, the European Investment Fund that established the Western Balkan Enterprise and Innovation Facility (WBEIF) for the Western Balkan countries. WBEIF consists of venture capital funds for investment in early stages of development (€40 million); business expansion ( $€ 55$ million); and guarantee schemes for entrepreneurs, small and medium-sized enterprises (worth $€ 25$ million) (SEVEN, 2015).

Earlier in the paper, when it was discussed about the incentive measures and activities of the Republic of Serbia in the sphere of regulating the legislative framework which should facilitate the business of the smallest economic entities; it was though the actions the country takes in the sphere of the formulation of new regulations on alternative sources of financing. One of the most recent steps that the Republic of Serbia has taken in this area is to amend the laws in the field of investment funds. More precisely, the Draft Law on Alternative Investment Funds was put on the Government's agenda during September 2019. This document prescribes the manner in which alternative financing models will function, in particular venture capital funds that are the bearers of the eponymous investments. According to the new Serbian regulation, venture capital funds are private equity funds whose assets are predominantly invested in newly established businesses or businesses that are in the initial stages of operations and, according to the management of the fund, show potential for growth (Ministry of Finance of the Republic of Serbia, 2019a).

Given these opportunities and the fact that the steps regarding the creation of conditions for venture capital investing have been made recently, the data presented in the following table will not come as a surprise. Namely, Table 2 shows the total amount of venture capital investments in the Republic of Serbia from 2014 to 2018; and in addition to the total values, there is data which upon analysis can help in revealing in which stage of development of the entrepreneurial entities, venture capital investments were most attracted to. The observation period covers the last five years; as it is by inspecting the statistical reports observed that there had been no such investments before 2014 on the territory of the Republic of Serbia (EVCA Central and Eastern Europe Task Force, 2014). This spreadsheet indicates a positive trend in the Serbian capital market regarding the successful implementation of this type of investment in the past period. 
Table 2. Venture capital investments (VCI) in the Republic of Serbia in the period from 2014 to 2018 (in thousands of euros)

\begin{tabular}{|l|c|c|c|c|c|}
\hline Stage of development of a company & $\mathbf{2 0 1 4}$ & $\mathbf{2 0 1 5}$ & $\mathbf{2 0 1 6}$ & $\mathbf{2 0 1 7}$ & $\mathbf{2 0 1 8}$ \\
\hline Seed & 0 & 0 & 80 & 300 & 400 \\
\hline Start-up & 0 & 423 & 1,000 & 1,200 & 3,465 \\
\hline Later-stage venture & 0 & 0 & 0 & 0 & 0 \\
\hline Total VCI & 0 & 423 & 1,080 & 1,500 & 3,865 \\
\hline
\end{tabular}

Source: Authors, according to data obtained from Invest Europe, 2016; 2018; 2019a.

However, regardless of the encouraging 2018 data related to the increase in these investments (when a historical maximum of almost $€ 4$ million was recorded), it is worth pointing out that the results so far are not impressive. The unsatisfactory results are confirmed by the insight into European market statistics for venture capital investments, where, as an example of good practice Finland and Denmark, which are leaders in terms of this type of financing can be highlighted. Namely, their venture capital investments account for $0.096 \%$ and $0.095 \%$ of national GDP respectively (Invest Europe, 2019b). In the Serbian case, in the year when the country had record amounts of venture capital investments (2018), the share of these investments in the national GDP was only $0.00000000009 \%$, which is presented in the table below.

Table 3. Trends of venture capital investments (VCI) and GDP in the period from 2014 to 2018 in the Republic of Serbia

\begin{tabular}{|c|c|c|c|}
\hline Year & VCI (millions of euros) & GDP (millions of euros) & VCI/GDP (in \%) \\
\hline $\mathbf{2 0 1 4}$ & 0 & $35,467.5$ & 0 \\
\hline $\mathbf{2 0 1 5}$ & 0.42 & $35,715.6$ & $0.000 \ldots$ \\
\hline $\mathbf{2 0 1 6}$ & 1.08 & $36,723.1$ & $0.000 \ldots$ \\
\hline $\mathbf{2 0 1 7}$ & 1.5 & $39,183.3$ & $0.000 \ldots$ \\
\hline $\mathbf{2 0 1 8}$ & 3.86 & $42,780.0$ & 0.00000000009 \\
\hline
\end{tabular}

Source: Authors, according to data obtained from the Ministry of Finance of the Republic of Serbia, 2019b; Invest Europe, 2016; 2018; 2019a.

\section{Entrepreneurship in the Republic of Serbia}

The sector of small and medium-sized enterprises and entrepreneurs is, individually observed, the most significant segment in the economies of almost all countries in the world. A healthy and dynamic sector of this type represents a stable source of new jobs, increasing employment, innovation, tax revenue 
generation through a contribution to the reduction of informal and grey economy, etc. Exploiting completely the potentials of entrepreneurs, small and medium-sized enterprises, in terms of their contribution to the growth and development of national economies and poverty reduction, is largely conditioned by the degree of institutional support provided by the state through their mechanisms. Encouragement of the development of the sector of small and medium-sized enterprises and entrepreneurs is defined as one of the priority goals of the economic policy of the Republic of Serbia. Small and medium-sized enterprises and entrepreneurs represent a significant factor in the recovery of the national economy, reflecting the stability of the financial assets through: employment, export, import, and investment (Ilić et al., 2018).

The results of numerous studies show that the sector of small and medium-sized enterprises and entrepreneurs represent a significant driving force for the economic development of every country and that it is a potential generator of entrepreneurial ideas and innovations. Namely, the main direction of the development of the mentioned sector is based on an innovative approach to the real needs of the market. The intensified transition process after 2000 made the sector of small and medium-sized enterprises and entrepreneurs the carrier of economic growth and employment, which gradually grew into the most dynamic and efficient segment of the economy of the Republic of Serbia (Kostadinović, Petrović-Ranđelović, 2015). Small and medium-sized enterprises and entrepreneurs are legal entities with less than 250 full-time employees (Statistical Office of the Republic of Serbia, 2018).

In 2017, there were 357,234 entrepreneurs, small and medium-sized enterprises in the Republic of Serbia, which was an increase compared to 2009 when 314,827 such economic entities operated in the Serbian market. This means that, in the observed period (from 2009 to 2017), the market received 12,407 new entrants, and what is encouraging is the fact that these values have a tendency of further growth. The aforementioned sector consists mostly of entrepreneurs which amounted to 344,279 in 2017 , or $96.4 \%$ (Table 4).

In addition, the same table gives an insight into the number of persons employed by this sector. Thus, it can be noted that entrepreneurs retain primacy in this category as well. Namely, this type of legal entities employed 415,762 persons in 2017 , which represents $47.6 \%$ of all persons employed in the sector of small and medium-sized enterprises and entrepreneurs. Compared to the beginning of the observed period (2009), it can be noted that the total number of employees remained at relatively the same level, and that employment in each of the mentioned types of companies recorded very similar values.

For a better understanding of the data presented below and the current situation in which entrepreneurs, small and medium-sized enterprises are, the figure below (Figure 2) will present an overview of the number of established and extinguished 


\begin{tabular}{|c|c|c|c|c|c|c|c|c|c|}
\hline 록 & 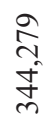 & $\begin{array}{l}\hat{\infty} \\
\tilde{n} \\
0\end{array}$ & 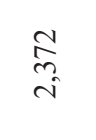 & 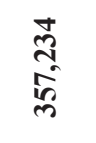 & $\begin{array}{l}\text { है } \\
\stackrel{n}{7}\end{array}$ & $\begin{array}{l}\infty \\
\infty \\
m \\
\stackrel{\sim}{\sim}\end{array}$ & 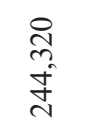 & 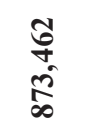 & $\begin{array}{l}\overline{0} \\
\overline{0} \\
\overline{0} \\
\overline{0} \\
\overline{0}\end{array}$ \\
\hline 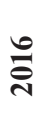 & $\begin{array}{l}n \\
\hat{b} \\
\text { in } \\
\text { ñ }\end{array}$ & $\begin{array}{l}\stackrel{+}{n} \\
0 \\
0\end{array}$ & $\begin{array}{l}\text { ڤ్ } \\
\text { î } \\
\text { i }\end{array}$ & 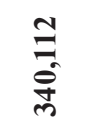 & $\begin{array}{l}\infty \\
\text { +े } \\
\text { í }\end{array}$ & 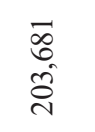 & $\begin{array}{l}\text { ô } \\
\text { त̃ } \\
\text { ते }\end{array}$ & $\begin{array}{c}\tilde{n} \\
\tilde{n} \\
\infty \\
\infty\end{array}$ & 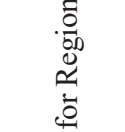 \\
\hline$\stackrel{n}{\stackrel{N}{n}}$ & $\begin{array}{l}\hat{\infty} \\
\infty \\
\stackrel{1}{m}\end{array}$ & $\begin{array}{l}\bar{n} \\
\hat{n} \\
\sigma^{2}\end{array}$ & $\frac{\widetilde{\infty}}{\sim}$ & $\begin{array}{l}\text { ठ } \\
\text { ले } \\
\text { ले }\end{array}$ & $\begin{array}{l}\stackrel{\infty}{N} \\
\stackrel{N}{\infty} \\
\infty \\
\infty\end{array}$ & 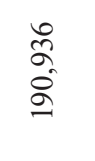 & 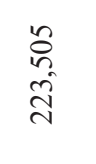 & $\frac{\mathscr{a}}{\bar{\sigma}}$ & 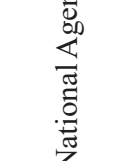 \\
\hline$\underset{\sim}{\stackrel{\sim}{二}}$ & $\begin{array}{l}\stackrel{m}{\sigma} \\
\stackrel{i}{\tilde{m}}\end{array}$ & $\frac{\infty}{a}$ & $\frac{\vec{m}}{\vec{i}}$ & 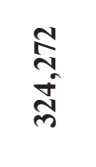 & $\begin{array}{l}\infty \\
m \\
n \\
n \\
n\end{array}$ & $\begin{array}{l}0 \\
\stackrel{0}{1} \\
\vdots \\
\infty \\
\infty\end{array}$ & 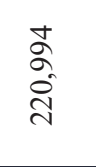 & 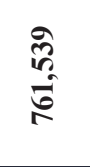 & 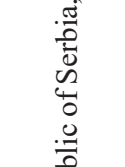 \\
\hline$\stackrel{\text { ֻ }}{\stackrel{\sim}{二}}$ & $\begin{array}{l}\hat{\sigma} \\
\hat{\sigma} \\
\hat{ల}\end{array}$ & $\begin{array}{l}\hat{\tilde{n}} \\
\tilde{\sigma}\end{array}$ & $\frac{\approx}{\sim}$ & $\underset{\frac{7}{7}}{\frac{1}{n}}$ & 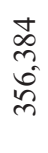 & $\begin{array}{l}\stackrel{\cong}{\cong} \\
\stackrel{0}{-}\end{array}$ & $\begin{array}{l}\text { ठू } \\
\text { ते } \\
\text { ते }\end{array}$ & 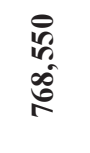 & 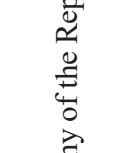 \\
\hline 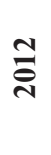 & $\begin{array}{l}\bar{N} \\
\text { n. } \\
\text { है } \\
\text { nd }\end{array}$ & $\begin{array}{l}\text { ठे } \\
\text { an }\end{array}$ & $\frac{\text { I }}{i}$ & $\frac{\widetilde{\sigma}}{\frac{\sigma}{n}}$ & $\begin{array}{l}\bar{m} \\
\vec{n}\end{array}$ & 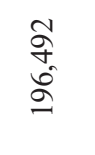 & 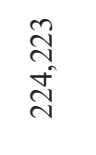 & 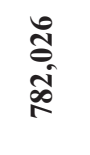 & 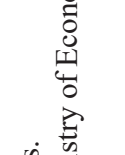 \\
\hline$\overline{\bar{\sim}}$ & 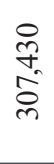 & 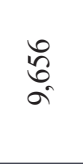 & $\begin{array}{l}\frac{\infty}{\sim} \\
\underset{\sim}{v}\end{array}$ & $\begin{array}{l}\stackrel{ \pm}{0} \\
\text { ă } \\
\stackrel{m}{m}\end{array}$ & $\begin{array}{l}\text { aे } \\
\infty \\
\infty \\
n\end{array}$ & 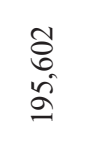 & 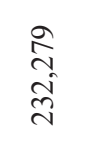 & $\begin{array}{l}m \\
\infty \\
\infty \\
\infty \\
\infty \\
\infty\end{array}$ & 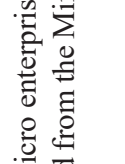 \\
\hline 록 & 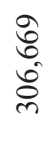 & $\begin{array}{l}\frac{\nabla}{\sigma} \\
\sigma^{\circ}\end{array}$ & $\begin{array}{l}\hat{n} \\
i \\
i\end{array}$ & $\begin{array}{l}\text { Pे } \\
\text { ch } \\
\frac{\infty}{m}\end{array}$ & \begin{tabular}{l}
$\stackrel{+}{f}$ \\
\multirow{2}{*}{} \\
$\infty$ \\
$\infty$
\end{tabular} & 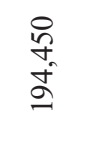 & 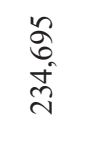 & $\begin{array}{l}\infty \\
\infty \\
\infty \\
\infty \\
\infty\end{array}$ & 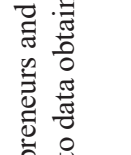 \\
\hline ஓ्ఠ̆ & 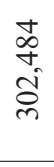 & $\frac{m}{\infty}$ & 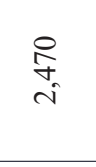 & 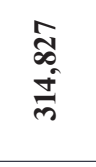 & \begin{tabular}{l}
$\hat{n}$ \\
$\mathfrak{f}$ \\
\multirow{\gamma}{*}{}
\end{tabular} & 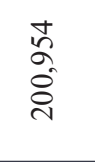 & $\begin{array}{l}\text { ते } \\
\text { ڤે } \\
\text { ते }\end{array}$ & 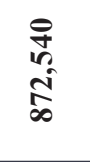 & 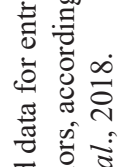 \\
\hline 苑 & & 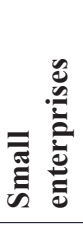 & 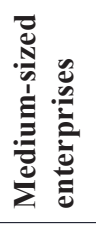 & 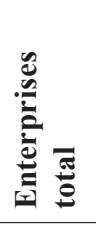 & 咅 & 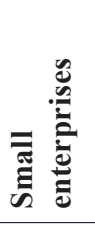 & 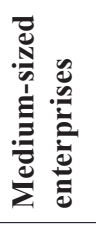 & 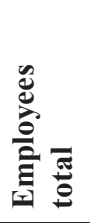 & 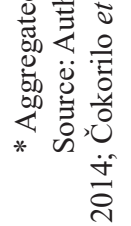 \\
\hline
\end{tabular}


enterprises in the Republic of Serbia from 2010 to 2017. Since 2013, the net number of enterprises was constantly increasing, with a particularly significant increase in value in 2016 compared to 2015 (from 6,498 to 17,316 companies). The reason for this situation is the decrease in the number of extinguished enterprises, not the increase in the number of newly established. Considering the fact that in the last few years the Republic of Serbia has taken active measures to encourage entrepreneurship (2016 was declared as the year of entrepreneurship), this data is not surprising. The improved business environment, which has strengthened additional capital investment in this sector, in addition to state support, was one of the main reasons for such positive results.

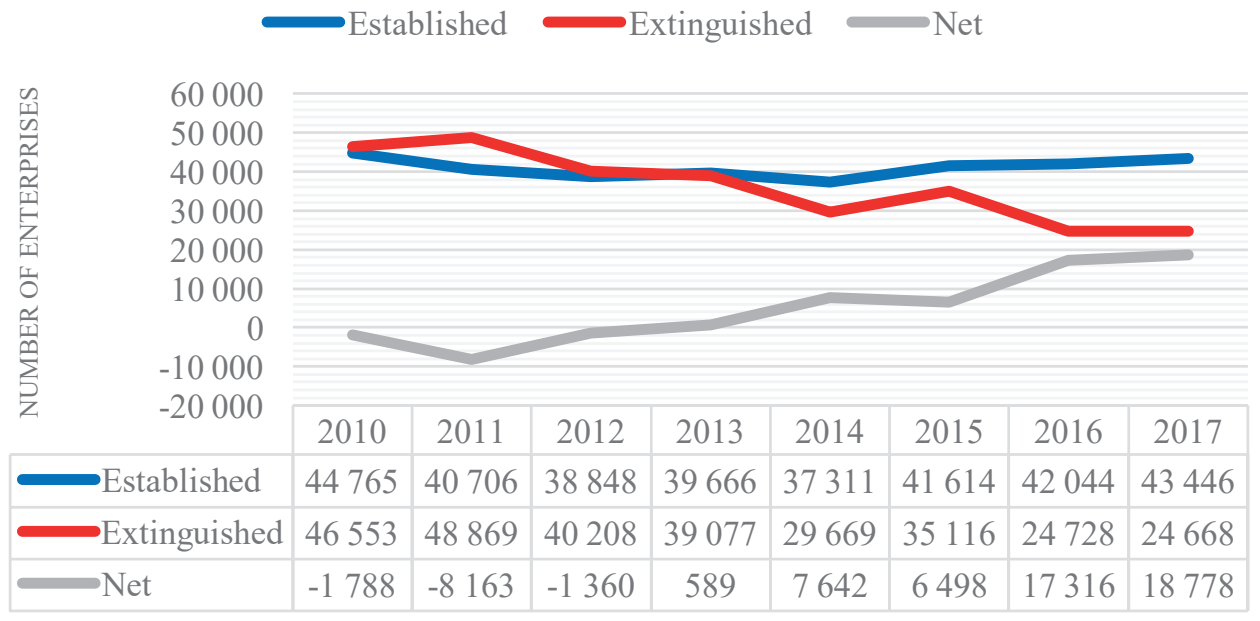

YEAR

Figure 2. The number of established and extinguished small and medium-sized enterprises and entrepreneurs in the Republic of Serbia from 2010 to 2017

Source: Authors, according to data obtained from Čokorilo et al., 2018.

The relatively low number of these entities that manage to survive in the market clearly indicates the problems they may face. As already pointed out in this paper, access to financial banking products in the Republic of Serbia is extremely difficult, and these companies must seek additional sources of income. This difficult access to funds is also evidenced by the ranking of the Republic of Serbia in relation to various financial indicators. Namely, this country in the world occupies (EY, 2018):

- $98^{\text {th }}$ position regarding the availability of financial services;

- $121^{\text {st }}$ position regarding access to credits; and

- $132^{\text {nd }}$ position regarding the availability of foreign capital. 


\section{Conclusion}

The research conducted above is dedicated to the examination of foreign direct investment and venture capital investment impact on small and mediumsized enterprises and entrepreneurs in the Republic of Serbia. This paper presents data on the volume of the aforementioned investments in business entities based on their size, organisational type, and the number of employees. Furthermore, the problems that arise from the characteristics of these entities: that is, lack of bank creditworthiness, credit history, and collateral were pointed out. Small and medium-sized enterprises and entrepreneurs are the most significant, the most represented, and the most endangered entities in the Serbian economy, so special attention is rightly paid to them. The state has recognised their vulnerability and has dedicated its resources to modify sectoral regulations in order to influence the creation of a decent financial environment necessary for minimizing the number of extinguished entities on an annual basis. Within this paper, the positive actions undertaken by the state are highlighted, with the included additional estimation that they need to be more frequent, methodical, and concrete in order to ensure faster development of the national capital market.

On the development scale, the foreign direct investment currently occupies a better position compared to the funds for similar purposes - venture capital investment. Namely, since 2012, foreign direct investments record constant increase, and in the last three years, their existence was characterized by significant positive jumps. In 2018, it has even been noted a record inflow of these investments. These are encouraging news for endangered small and medium-sized business entities which will continue to benefit considerably from the positive effects caused by these investments. On the other hand, venture capital investments are extremely undeveloped in the Serbian capital market, especially when compared to the level of these investments in developed European economies. The utilisation of these investments at the European level is an indisputable indicator of the importance of attracting them to the national market. There is no doubt that investments of this type represent a back wind to the entrepreneurship of any country they gravitate to.

Both foreign direct investment and venture capital investment are characterised by investing in companies for the purpose of taking one part of their property and exploiting benefits which that property offers. This is especially evident in the case of venture capital investments which are aimed at high-risk entrepreneurial businesses that are at the very beginning of operations and usually oriented to the development of new technologies. Capitalists invest in a large number of entities with these characteristics, aware that at least $90 \%$ of their money will be wasted, but also expecting that at least one of their 'financial protégés' will achieve excellent market results, provide funds that will repay all previous investment failures, and bring in additional profit. Further, the 
capitalists will estimate whether the sale of the ownership share in mentioned entities is justified and profitable at that moment, or it is worth to wait in order to achieve a substantial profit. Evidently, the level of risk to which the capitalists are exposed is very high in all phases that the recipient entity goes through, but it is a position to which they have agreed. Nevertheless, more than to capitalists, these investments mean to the entities that absorb them.

Small and medium-sized enterprises and entrepreneurs have difficulties with funding, i.e. they often can not take loans on the banking financial market. Even if they can, it is generally under extremely unfavourable conditions. According to this situation, entities with a lack of capital have three alternatives at their disposal: seeking partners, attracting foreign investment, or extinguishing their businesses. A potential partner could be a resident of the same country, with the capacity to solve the problem that the entrepreneur is struggling with. On the other hand, a foreign investor in addition to capital can offer multiple benefits to the company, and the most important among them is managerial support (investor makes his management team available to the investment recipient, and directs its knowledge and experience towards improving the performance of the mentioned entity). Empowered with the capital and backed up by a quality management structure, this entity can dedicate to the development of its own idea, with upgrading its products and improving performance by applying new technologies. In this way a likelihood of achieving success increases. At the very end, it is not difficult to conclude that among available alternatives that the entity has, an attraction of foreign investment is the most favourable one.

The research highlighted the fact that foreign direct investment and venture capital investment, according to their characteristics, are suitable for different types of companies. Thus, foreign direct investments reach the greatest effects when investing in later-stage businesses, i.e. entities that already have developed products and harmonised production process, use relatively old technology, slowly enter into the phase of stagnation, and need a 'refreshment' in the form of new capital. With such investments, these entities receive the financial resources necessary to encourage the development of new ideas. This whole process is aided by quality human resources (management teams), whose experience and enviable market knowledge can provide entities' rapid and unhindered growth. On the other hand, venture capital investment should be exclusively directed towards small, high-risk entrepreneurial businesses, that plan to develop products/ services in promising, usually technologically demanding industries. By using these investments, entities renounce only a minor share of ownership, and in turn, receive enviable support in staff and capital.

In accordance with all the facts stated in this paper, it is possible to analyse the fulfillment of the research hypothesis set at the very beginning; thus:

- the hypothesis H1: 'Financing Serbian entrepreneurship with foreign direct investments influences the empowerment of entrepreneurial businesses due to the 
involvement of new players in the management structure of these entities' is fully confirmed. Namely, the existing practice of the positive impact of institutional investors on the company's operations after acquiring the right to manage and control it through the purchase of ownership shares was emphasized in the paper;

- the hypothesis H2: 'Financing Serbian entrepreneurship with venture capital investments influences the development of ideas and innovations and encourages the technological development of entrepreneurial entities' is fully confirmed. As already emphasised, venture capital investments are intended for promising and innovative entities dealing with modern technologies and their implementation in the production process. When a company with this sphere of business receives financial support, it directs it to the most important segment of its operations - knowledge. Consequently, entrepreneurs become motivated by the fact that their idea was recognised as valuable at the market, so optimistically continue their work with encouragement to present and other innovative projects to it. With the necessary capital, these entities effortlessly create prototypes of their products, and at the same time have enough funds left to deal with other innovative experiments;

- the hypothesis H3: 'Financing Serbian entrepreneurship with foreign direct investment and venture capital investment influences the increase of the financial stability of entrepreneurial entities and their chances of survival in the market' is fully confirmed. This hypothesis is confirmed by the data in Table 1, Table 3 , and Figure 2 which indicate a potential correlation between an increased number of foreign direct investment and venture capital investment, and a reduced number of extinguished entities in the same period in the Republic of Serbia;

- the basic hypothesis of the research, H0: 'Foreign direct investment and venture capital investment have a positive impact on entrepreneurship in the Republic of Serbia' is fully confirmed by virtue of data presented in the paper and validation of specific hypotheses that determine it more closely.

Based on everything presented, it should be noted that alternative sources of financing (foreign direct investment and venture capital investment) could be the main drivers of development for promising small and medium-sized enterprises and entrepreneurs. In this way, mentioned entities undoubtedly could be empowered and focused on the smooth realisation of their business ideas, and cumulatively, their operations could contribute to the growth and prosperity of the entire Serbian economy. 


\section{References}

Čokorilo, N., Nikolić, S., Milošević, S., Trajković, M., Ćurić, S. 2018. Izveštaj o malim $i$ srednjim preduzećima i preduzetništvu za 2017. godinu. Belgrade: Ministry of Economy of the Republic of Serbia, Sector for Small and Medium-sized Enterprises and Entrepreneurship.

EVCA Central and Eastern Europe Task Force. 2014. Central and Eastern Europe Statistics 2013. Brussels: European Private Equity and Venture Capital Association.

EY. 2018. EY Preduzetnički barometar. Belgrade: Ernst \& Young d.o.o.

Ignjatijević, S. 2015. Ekonomska analiza značaja stranih direktnih investicija. Oditor - časopis za menadžment, finansije i pravo 11, pp. 1-15.

Ilić, S., Radonjić, A., Andrić, N. 2018. Značaj sektora MSPP za privredni razvoj Republike Srbije. Proceedings of Second International Scientific Conference EMAN 'Economics and Management: How to Cope with Disrupted Times'. Ljubljana: Association of Economists and Managers of the Balkans.

Invest Europe. 2016. Central and Eastern European Private Equity Statistic 2015. Brussels: Invest Europe.

Invest Europe. 2018. Central and Eastern European Private Equity Statistic 2017. Brussels: Invest Europe.

Invest Europe. 2019a. Central and Eastern European Private Equity Statistic 2018. Brussels: Invest Europe.

Invest Europe. 2019b. European Private Equity Activity: Statistics on Fundraising, Investments \& Divestments. Brussels: Invest Europe.

Investopedia. 2019. Venture Capital Funds, https://www.investopedia.com/terms/v/ vcfund.asp (accessed 14.08.2019).

Kastratović, R. 2016. Uticaj stranih direktnih investicija na privredni i društveni razvoj Srbije. Bankarstvo 45(4), pp. 70-93.

Kostadinović, I., Petrović-Ranđelović, M. 2015. Značaj unapređenja konkurentnosti sektora MSPP za razvoj privrede Republike Srbije. Ekonomske teme 53(2), pp. 253-272.

Makroekonomija. 2013. Strane direktne investicije - instrumenti eksploatacije, https:// www.makroekonomija.org/strane-direktne-investicije/strane-direktne-investicijeinstrumenti-eksploatacije/ (accessed 15.08.2019).

Metrick, A. ed. 2007. Venture Capital and Finance of Innovation. New York: John Wiley \& Sons.

Milenković, N., Kalaš, B. 2018. Distinkcija i položaj fondova rizičnog i privatnog kapitala. Kultura polisa 37, pp. 385-296.

Milovanović, G., Radisavljević, G., Đukić, G. 2018. Dependence of Serbian Economic Development on Foreign Direct Investment Flows. Ekonomika 64(2), pp. 33-42.

Ministry of Economy of the Republic of Serbia, National Agency for Regional Development. 2014. Izveštaj o malim i srednjim preduzećima i preduzetništvu za 2013. godinu. Belgrade: Ministry of Economy of the Republic of Serbia, National Agency for Regional Development.

Ministry of Finance of the Republic of Serbia. 2019a. Nacrt Zakona o alternativnim investicionim fondovima, https://www.mfin.gov.rs/UserFiles/File/javne\%20 
rasprave/2019/Nacrt\%20Zakona\%20o\%20alternativnim\%20investicionim $\% 20$ fondovima.pdf (accessed 19.08.2019).

Ministry of Finance of the Republic of Serbia. 2019b. Public Finance Bulletin 1/2019. Belgrade: Ministry of Finance of the Republic of Serbia.

Nestorović, O. 2015. Strane direktne investicije kao faktor održivog razvoja privrede Srbije. Doctoral diss. Kragujevac: University of Kragujevac, Faculty of Economics.

OECD (Organization for Economic Co-operation and Development). 2008. OECD Benchmark Definition of Foreign Direct Investment. 4th edition. Paris: OECD Publishing.

Statistical Office of the Republic of Serbia. 2018. Statistički godišnjak Republike Srbije. Belgrade: Statistical Office of the Republic of Serbia.

SEVEN (Serbian Venture Network). 2015. Politike i mere podrške za razvoj preduzetništva u Srbiji, https:/www.pokreni.se/wordpress/wp-content/uploads/2015/03/Policybrief.pdf (accessed 17.08.2019).

Stefanović, M. 2008. Uticaj stranih direktnih investicija na razvoj nacionalne ekonomije. Ekonomske teme 46(2), pp. 131-145.

Šabić, D., Vujadinović, S., Milinčić, M., Golić, R., Stojković, S., Joksimović, M., Filipović, D., Šećerov, V., Dimitrijević, D. 2012. The Impact of FDI on the Transitional Economy in Serbia - Changes and Challenges. Acta Polytechnica Hungarica 9(3), pp. 65-84.

Šušić, M. I., Spasojević, B. 2016. Strane direktne investicije i njihov značaj u finansiranju globalne ekonomije. Poslovne studije 15-16, pp. 119-139.

UNCTAD (United Nations Conference on Trade and Development). 2019a. Annex Table 1. FDI Inflows, by Region and Economy, 1990-2018, https:/unctad.org/en/Pages/ DIAE/World\%20Investment\%20Report/Annex-Tables.aspx (accessed 16.08.2019).

UNCTAD (United Nations Conference on Trade and Development). 2019b. Annex Table 2. FDI Outflows, by Region and Economy, 1990-2018, https://unctad.org/en/Pages/ DIAE/World\%20Investment\%20Report/Annex-Tables.aspx (accessed 16.08.2019).

UNCTAD Secretariat. 1997. Experiences of Country Funds and Venture Capital Funds in Developing Countries, https://unctad.org/en/Docs/pogdsgfsbd1.en.pdf (accessed 16.08.2019).

Vidas-Bubanja, M. ed. 1998. Metode i determinante stranih direktnih investicija. Belgrade: Institute of Economic Sciences.

Zider, B. 1998. How Venture Capital Works, https://hbr.org/1998/11/how-venture-capitalworks (accessed 19.08.2019). 